\title{
Secrets in The Lagoon and Other Stories
}

\section{Christine Lorre}

\section{(2) OpenEdition}

1 Journals

Electronic version

URL: https://journals.openedition.org/ces/8160

DOI: $10.4000 /$ ces.8160

ISSN: 2534-6695

\section{Publisher}

SEPC (Société d'études des pays du Commonwealth)

\section{Printed version}

Date of publication: 1 April 2011

Number of pages: 87-97

ISSN: 2270-0633

\section{Electronic reference}

Christine Lorre, "Secrets in The Lagoon and Other Stories", Commonwealth Essays and Studies [Online] 33.2 | 2011, Online since 18 November 2021, connection on 06 January 2022. URL: http:// journals.openedition.org/ces/8160 ; DOI: https://doi.org/10.4000/ces.8160

\section{(c) (i) (5)}

Commonwealth Essays and Studies is licensed under a Licence Creative Commons Attribution - Pas d'Utilisation Commerciale - Pas de Modification 4.0 International. 


\section{Secrets in The Lagoon and Other Stories ${ }^{1}$}

Secrets abound in The Lagoon - be they children's secrets, personal quests for meaning, or secrets that remain illegible even to the subject, they are mostly overshadowed by the perspective or the personal experience of death. This article relies on Jacques Derrida's ideas on the secret, both as something related to the ineffable and as an inaccessible inner core, to sound the depth of this figure's resonance in Frame's stories.

Janet Frame's complex writing triggers many questions of interpretation - a situation that Frameworks, the 2009 book of essays edited by Jan Cronin and Simone Drichel, addresses. In particular, Drichel, in "Signposts to a world that is not even mentioned," raises "the question of how Frame's 'transcendent urge' should be best described" (184). Drichel starts with a critique of the concept of utopia in Marc Delrez's book-length study, Manifold Utopia (2002), to examine "Frame's seemingly insatiable desire for a beyond" (183). She herself proposes calling Frame's urge "“ethical' - in the specific sense given to that word by Emmanuel Levinas" (184-185), and engages in a reading of Intensive Care in that light. In Frameworks again, Jan Cronin, in "Through a Glass Darkly: Reading the Enigmatic Frame," suggests approaching Frame's work as a sort of enigma. Unlike a riddle, which in Paul de Man's definition is "a mere deferment of a known secret" (Cronin 5), an enigma "does not necessarily have a definite answer" (6). In their hermeneutic investigation of Frame's work, both Cronin and Drichel, in the two essays that bracket the critical volume they co-edited, insist that Frame's texts present "simultaneously prescriptive and provisional, and fixed and fluid, features" (Cronin 5), so a critical essay "must resist the very interpretative closure it invites" (Drichel 186).

In order to examine some aspects of Frame's "transcendent urge" to describe the self, while engaging in the kind of open interpretation that her work calls for, I will start from the figure of the secret. It is an important literary motif in The Lagoon, as William New points out in his essay in this issue (36), and it can also act as a compelling conceptual tool, as Jacques Derrida has shown. I will argue that when declaring that "her works are "signposts to a world that is not even mentioned"" ("Alone" qtd. in Drichel 185), Frame alludes to a sense of her writing that prefigures Derrida's understanding of literature as something that in principle implies a right to say everything and to hide everything, ${ }^{2}$ and that can be connected with the concept of "writing under erasure" (De la grammatologie 38). This critical position is echoed in Janet Wilson's observation in this volume that "in despair of any other language with which to speak, [Frame adopts] the practice of writing under erasure" (132). ${ }^{3}$

1. I wish to express my heartfelt gratitude to the Stout Research Centre for New Zealand Studies and its director, Lydia Wevers, for welcoming me as a Visiting Scholar in 2007. This work on Frame's short fiction is an outcome of my time there.

2. Derrida declares, "la littérature [...] implique en principe le droit de tout dire et de tout cacher" (Donner 206). Warmest thanks to Anne Berger for her reading suggestions on Derrida and the secret.

3. See also Guignery 313-314. 
The word secret has religious origins and has retained its original proximity with the sacred; it often refers to something leaning towards the mysterious. The New Shorter Oxford dictionary gives us a range of meanings that suggest more ordinary understandings of the word, as well as sacred or mysterious ones, including "kept hidden or private from all or all but a few"; "beyond unaided human apprehension or intelligence"; "not openly admitted to, concealed, disguised"; "inward, inmost"; "hidden from sight, unseen" ("Secret" 2750). We will see how these various uses of the term appear in Frame's stories, before focusing on a particular acceptation. In her book on Derrida and the secret, Ginette Michaux examines how Derrida articulated a whole new meaning of the word "secret," another possibility of secret which would simply not be conditional on speech or language (Michaux 16). ${ }^{4}$ This larger secret resists decrypting as deciphering; it is an illegible, undecipherable secret rather than an invisible one to be discovered or unveiled. ${ }^{5}$ Derrida sees the early signs of this evolution towards a more illegible secret in the difference of meaning between the Latin absconditus, and the Greek crypt, words that became synonymous with the secret. The former privileges the visual dimension of the secret (hidden from sight), whereas the latter goes beyond the visible and includes anything that resists deciphering (Donner 123-124). Derrida deals with the aporia of an illegible secret in two ways: through literature and psychoanalysis. He considers that after Freud used the concept of the secret in the context of analysis, in its relation to repression, he changed the meaning of the word and opened an entirely new range of possibilities that have in common the illegibility of the secret. This is what Derrida calls the "postpsychoanalytical secret" (qtd. in Michaux 20). ${ }^{6}$ As for literature as an approach to the secret, he envisages a new form of reading which would consist not in a hermeneutic approach, but would be akin to a secret experience about a secret (Donner 164). I would like to argue that when she talks of "signposts to a world that is not even mentioned," this is the kind of secret that Frame has in mind - the very core of the self which may remain unknown, even to oneself.

The secrets that are found in The Lagoon vary in form, but they all point to the fact that every secret is somehow linked to death, and that a secret may never be totally deciphered (see Derrida qtd. in Michaux 28). There are many children's secrets that are part of a joyous economy of friendships and complicity. However, death is never far off and acts as an underlying mystery, something children do not fully understand, and that provides them with a first glimpse into the world of adulthood. The secrets that haunt some adults' lives and that underlie their quests for meaning, for all their apparent simplicity, touch upon the mysteries of life and death. Other secrets - and other selves - remain illegible.

4. Derrida gave a seminar on the secret at the EHESS (École des Hautes Études en Sciences Sociales) in 1991. Parts of it were published in Donner la mort (1999), and Ginette Michaux has commented on unpublished parts of the seminar that she quotes in Tenir au secret (2006). More generally, the secret is a recurrent figure throughout Derrida's work.

5. In Derrida's words, “ce qui résiste au décryptage comme déchiffrement: le secret comme illisible ou indéchiffrable plutôt que comme invisible" (Derrida qtd. in Michaux 19).

6. On Derrida and psychoanalysis, see also Michaux, "Lui." 


\section{Playmates and soulmates}

Children relish secrets, as a source of intimacy, ways of bonding, gestures of love. Their meaning is not spelt out, and they are usually simply referred to as "secrets," as if what they are about goes without saying, or cannot be expressed. Yet they remain the cryptic signs of the mysterious things they touch upon, things that can still be difficult to grasp and put into words - friendship, love, growing up, sex, adulthood, and also death. Secrets are crucial to childhood friendships. Because they involve sharing, they establish complicity. But they also involve excluding those who are not in the know, especially adults, so they act as invisible barriers that isolate children from the world of adults and create a world of their own. In that sense, they are part of the system of "fences of being" analyzed by Cindy Gabrielle in her essay. Often they are like secret codes, and what matters is the sharing of the code itself, not the message. This is what happens in "My Cousins - Who Could Eat Cooked Turnips," where a curious act of communication takes place. ${ }^{7}$ The story hinges on a moment of revelation that marks a shift, from the narrator's persistent feeling of alienation from her Invercargill cousins to sudden understanding: "And then we understood" (47). However she does not say what it is that she and her two siblings understand, but bow they do - by eating cooked turnips. When visiting their cousins, the children do not even talk to them, because they seem so different from them. But by deciding to eat the dreaded cooked turnips like their cousins, the children find a common code with them that enables them to communicate - and this is the important thing that they understand. By placing themselves in a similar position of obeying their parents' order - "eat your turnip" $(44,45)$ - they accept the common status of obedient children, while simultaneously stepping over the boundary that separated them from their cousins, namely the social practice of eating cooked turnips, and leaving the fold of their parents' familiar world. This movement is reflected in the language the children use, and the secrets Nancy shares with Mavis: "I don't suppose you know what this word means, and I whispered a word in her ear, and Mavis said I do too. I know lots of words" (47). By playing this game, the two girls perform what Roman Jakobson called the metalinguistic function of language (217-218): they are checking the meaning of the words of a language they are in the process of learning. What matters here is not so much the actual meaning of words, but the act of sharing them, the bonding that is produced through language. If this happens out of earshot of adults and other children, then it is a secret, even though this delicious word has not been pronounced yet. As Derrida points out, sharing a secret is not about knowing or disclosing a secret; it is about sharing something without knowing what this thing is: it is not something you know, nor something that can be determined (Donner 112). This is an essential value of the secret.

"My Father's Best Suit" similarly suggests that the sharing of a secret language is the essence of intimacy. In contrast with the father's seriousness and his concern to remain decent despite the economic depression, his daughters are joyful and write an imaginary story with creative means: "We wrote in invisible ink with lemon, and we

7. Parts of my analysis of "My Cousins" and "The Day of the Sheep" in this essay also appear in a forthcoming article entitled "Narrative Voice and the Making of the Self: A Study of The Lagoon and Other Stories." 
wrote spidery writing with green feathers, and we wrote with the blood of dahlias" (105). Their colourful writing - yellow, green and red - contrasts with the grey of their father's suit and his somber prospects. The story they write is full of a life and energy the source of which remains secret.

The type of secrets that children share, and which establishes an economy of the secret, with its alliances, intimacies, friendships, exclusions and inclusions, is sometimes found in the world of adults, but then it is as if adults have outgrown these secrets and that makes them quite petty. Frame's treatment of such situations is satirical. In "On the Car," the other passengers react instinctively to the drunk man who gets on: "They smiled secretly and they looked a little bit embarrassed to be caught smiling, so after they had stared and smiled they turned away, to talk or look at the advertisements" (117). The vaguely exchanged smiles are the sign of an implicit understanding among the passengers: the man is drunk and he is not one of theirs, he is not to be treated with ordinary civility, should he try to communicate; indeed the drunk man's conversation remains one-sided. But because they realise they are being mean, and because they are not that close together anyway, the passengers break the spell of this momentary communion by turning away and end up "shrinking further and further into their greatcoats" (118). In "A Beautiful Nature" the economy of the secret is even more basic. Edgar does not tell his fellow boarders that he has been given the sack, and instead spins a tale about why he had to leave his job. The others giggle, murmur and talk about him behind his back, while smiling to him and saying hello when he is in their presence. Mrs Michael, after giggling with the others, "smiled dutifully. She belonged to the Church. He has a beautiful nature, she said profoundly" (114). Frame denounces the social hypocrisy that prevails towards people like Edgar, and by ending the story on Mrs. Michael's words, she focuses on the false virtue of religious people who claim to have a deeper understanding of the human soul than others, but who side with mockery when it comes to social bonding. The boarders share a hidden code of communication, like the ones children use to reinforce cohesion among themselves, but its main effect is to contribute to Edgar's social exclusion.

To return to children's secrets, in "Child" a budding friendship is evoked. It is sealed when Jan and Minnie walk home together and take turns at whispering "Eleven twelve thirteen fourteen fifteen" (80), the formula that made them accomplices and led to their joint punishment. The whispering precedes their reciprocal declaration that they are each other's best friend. It is like a secret vow that they make to each other, without anyone else hearing. But there is another secret in "Child," which is beyond Jan's understanding. She gets the sense of it when she considers Minnie's macrocarpa hedge, which "was dark and mysterious and unknown" (81). The macrocarpa hedge is uncanny; it represents a secret Jan cannot fathom. Symbolically, the plant is traditionally associated with death - or life (Chevalier and Gheerbrant 334335), which can be linked to the fact that Minnie is an orphan. Jan insists on the fact that Minnie's hedge is different from hers: "[Minnie's] hedge was macrocarpa and ours was African Thorn. And she didn't have a mother and a father, she lived with her grandma and grandad" (80). The hedge is part and parcel of Minnie's identity; it defines and delimits who she is, and makes her different from Jan. The "unknown and terrifying" macrocarpa hedge (81) that borders her house is presumably Jan's first 
contact with the territory of death, and she feels out of her depth: "If I'd climbed it I wouldn't have known where to put my feet or which branches were safe" (81). The secret nature of the macrocarpa hedge is linked to the fact that it is associated with death, a ground that Jan does not feel safe exploring. And although she envies Minnie her freedom for not having a mother, she keeps coming back to her own. For children, secrets have to do with the apprenticeship of language and its astonishing function of communication rather than its referential function (Jakobson 214, 217). Through the apprenticeship of language and the sharing of secrets, they learn about the mysterious alchemy of friendship and pleasure, but also about the uncanniness of death, which in some stories becomes a lived experience.

\section{Death on the horizon}

The story entitled "The Secret" can be read as a narrative about what a secret means to a child. The mother decides to tell her daughter Nini about the likely death of her older sister Myrtle because of her heart condition. By taking her daughter aside and setting her apart from her group of younger siblings, the mother is creating the conditions for a secret to be told - the Latin word secretus originally meant "separate, set apart." Even though Nini is curious at first, she does not want to share the sad secret of her sister's possible death. She wants secrets that are full of promise and excitement, joy, glamour, the future, like the ones she used to share with her sister: Myrtle's "secret smiles and giggles" about Vincent, her boyfriend (11) hint at promises of romance; Nini's "secret resemblance to Janet Gaynor" (12) bestows on her the potential of a Hollywood star, and is also a sign of love in the eyes of the beholder. So Nini simply denies the truth of what the doctor said, as a way to keep her fear of her sister's death at bay. However, by the time the story gets told, Myrtle has died, as the past tense of the first sentence indicates ("My eldest sister was called Myrtle," 11, emphasis mine). So "The Secret" is really about two secrets: the secret of Myrtle's announced death, which the mother wants to share with Nini, and the cherished secret of Myrtle's friendship with her sister. That is the secret Nini, presumably a grown-up narrator now, wants to treasure, and the one that gets told in the story, thus totally screening off Myrtle's actual death and leaving it out of the narrative - except for the past tense of the first verb.

"Keel and Kool" relates a moment of frustration for Winnie, as she is reminded of the loss of her dead sister, Eva, through the presence of Joan. "Joan had been Eva's best friend. [...] She had secrets with Eva. They used to whisper together and giggle and talk in code" (25). Joan and Winnie play together, but they quickly become rivals for Eva's friendship, and Winnie is losing. Eva and Joan's friendship is proved by the secrets they used to share, and which Joan boasts about to Winnie. To make up for this, Winnie makes up her own code, “making pine-needle writing in the air" (27), and accuses Joan of being a liar, thus undermining her claim to be the closest person to Eva. The pine tree is an important element in the story. For Winnie it is conducive to reflecting and day-dreaming. After arguing with Joan, it becomes a refuge, and it is also a place where she can mourn Eva $(24,28,29)$. As in "Child," climbing up a tree or a hedge is a way for the child to elevate herself above her current worries, to establish some distance between herself and the world, to screen herself off. The 
hedge or tree is a familiar place where she can nest (but Minnie's macrocarpa is unfamiliar and threatening). But for Winnie there is no one to share her secrets with in the pine tree: no one answers when she whispers a new formula, a new code to share with her sister. A potential place for secrets and complicity, the pine tree turns into a place for mourning. But the two may not be opposed: mourning is also a secret, a process that happens in the inner self and may not be disclosed.

The moment of climax in "Swans" is when the mother and her two daughters cross the lagoon to get back to the train station: "They looked across the lagoon then and saw the swans, black and shining [...]. Why, the lagoon was filled with swans, like secret sad ships, secret and quiet" (65). The adverb "then" usually marks simultaneously a rupture with what precedes, and the occurrence of something important. Everything that happens then is exclusively linked to the protagonists' senses; this is the moment of revelation of a secret, and sight is dominant at first they looked and saw. As Derrida has observed, the penetration of secrets is often entrusted to sight rather than to hearing, smell or touch (Donner 122). The swans thus appear to the eye as the visible embodiment of "the visiting dark," "the dark black water, secret" (65), its metamorphosis in the animal world. However, in this scene, the other senses are called upon too, with an abundance of sounds, of "murmurings and rustlings": "Hush-sh the water said, rush-hush, the wind passed over the top of the water, no other sound but the shaking of rushes and far away now it seemed the roar of the sea like a secret sea that had crept inside your head forever" (65). Already there is the sense that even though this is a moment of revelation, not everything will be unveiled to sight, and the secret will remain invisible, that is to say illegible, undecipherable. So one can only guess at the secret the swans, "like secret sad ships," impart. The simile suggests that they are like vessels that convey meaning. The image of the ship also suggests a voyage, the voyage of life. They are black and match the surrounding darkness. They appear as the negative image, in photographic terms, of the world, and seem to confirm that the family has "walk[ed] into another world that had been kept secret from everyone and now they had found it" (65). It is an uncanny world, and it touches upon the larger secrets of life that remain unspoken. Here Frame manages to convey it all without disclosing the secret she is evoking (see Derrida Passions, 67-68). The black swans in the darkness, as a reverse image of traditional white swans in daylight, intimate at the unconscious, the other part of the mind that remains largely hidden from the self as well as from others. Yet there is a sense that these two worlds are not separated. While the protagonists are treading on the uncharted territory of the night, they still feel that they are on seemingly familiar ground, and they can sense the quiet and calm around them.

That the hidden world they enter is also the world of adulthood is suggested through the motif of the lagoon, a liminal space between sea and land, between beach and home. It thus appears as a symbolic space between childhood and adulthood, a space where a new experience can be taken in with confidence. The scene of the apparition of the swans is literally taken in: "a secret sea that had crept inside your head forever." It is a form of initiation to adult life. The other world the protagonists enter is the world of adulthood, but it is also larger than that. The mother is living the same experience as her daughters, for she is a child-like figure to some extent, in her naivety (believing that the cat will be all right) and her hesitations (was it the wrong 
beach?), even though she acts "as if she knew, and she did know too, Mother knew always," adds the child's voice (58). But what the reader and narrator find out is that this is a lie: Mother does not always know. She was wrong about the cat: it was not all right, it died. The story of the cat frames the narrative, with a page and a half devoted to it at the beginning, and two lines in the anticlimactic end. Obviously the cat's death has been pushed to the back row after the experience at the beach, because death has been apprehended in a different way from the death of the cat in the familiar environment of home. The potential drama of the cat's death has been deflated: the children have grown up and the narrative voice suggests that they take its death with relative detachment.

\section{Quests for meaning}

The lagoon once more acts as a liminal space in the title story, where the protagonist is in search of a story about her late grandmother. The secret she is after is tied to place - it is revealed to her during her holiday in Picton, her grandmother's hometown - but it is also one she carries in her head in the form of stories her grandmother told her about the lagoon, recalling "the secret sea" in "Swans" (65). Her grandmother told her about the lagoon and the occasional "underwater moon, dim and secret" (3). The mention of the moon in connection with the lagoon adds a feminine dimension to the mystery of the place. The landscape is further linked to the uncanny with the mention of the bush on the hills around the harbour, "with its secret terrible drippings and rustlings that go on for ever" (5), and the fearsome gorse, which contribute to a gothic atmosphere. The protagonist used to beg for stories but she feels that the landscape her late grandmother is linked to has not revealed everything yet. By visiting her aunt, she goes back to the family on an unspoken search for family secrets that her grandmother might have taken with her into her grave, as the saying goes. She seems particularly intrigued by her grandmother's Maori mother, but as Mark Williams argues in his essay, "It is as though in reaching back to the colonial world the narrator finds only other narratives, invented by herself and her family," so her search for secret is a disappointing experience, "without the glamour of the ancient world or the signs of that true belonging Maori ought to display" (74). This search starts with looking at family photographs with her aunt, but sight is not enough to disclose a secret - she needs stories, that is to say memory. The story of the murderous great-grandmother comes out of the aunt, who does give it the seal of a family secret: "But then nobody knew, only the family" (6-7). The story the aunt tells also conveys a sense of unreliability ("I suppose the tide was high, I don't know," 6), of non-exclusiveness, with the alternative story of the grandfather having been drunk and having drowned himself, and of inaccessible truth. The story ends on words children say in their game, "you be Father I'll be Mother and we'll live here and catch crabs and tiddlers for ever..." (7). "For ever" belongs to the time of childhood, with its absence of a sense of time, and the impression that things will actually last forever, when adults know that life is ephemeral with death as its endpoint. It is the same "for ever" as the one found in "Swans" in "the darker the world outside got the safer you felt, for there were Mother and Father always, for ever" (64). But like the children in "Swans" who apprehend mortality that day, the protagonist of "The Lagoon" gets a 
sense of mortality through the secret about the great-grandmother that does get passed on, although it is shrouded in uncertainty. She has nothing to hang on to, and yet she does have her grandmother's stories. So the family secret she gets to hear in the end is a secret in the sense that Derrida gives it: you do not know what the shared secret is; it is a passion that cannot be passed on from one generation to the next, so it does not have a history. Yet it tells you that you need to always start over (Donner 113). In other words, the secret is not a truth, but a trace.

In "The Day of the Sheep," the secret that frames the narrative takes on a quasireligious dimension. In the opening paragraph, a god-like narrative voice addresses the elements ("Tell her, blackbird [...] and rainwater [...] and dirty backyard," 69) in order to help Nance make sense of the day which was like "a leafless cloudy secret hard to understand" (69). Yet Nance feels lost throughout, because "the language [is] something she cannot construe having no grammar of journeys" (69), so the invisible poetic side of her prosaic life is never revealed to her. She does not look beyond the visible of the daily grind, does not lift her eyes up from the daily muddle she craves to escape, the dirt that has to be gathered, the slime of the washing water, the sheep-dirt she remembers from childhood. Although the terms used by the god-like narrative voice are echoed in Nance's voice at the end, as the words of a priest are repeated by a congregation, she does not understand the language of it: "we're always in other places, lost, like sheep, and I cannot understand the leafless cloudy secret and the sun of any day" (75). By the end of the story, Nance is defeated by her daily life because she lacks faith. What she hopes for is to "go away from here" (69), but then she wonders about the meaning of going, the sense of that possible journey. She still pictures herself as "muddling backwards and forwards in little irrelevant journeys" (74) and ponders, "it would be nice to travel if you knew where you were going and where you would live or do we ever know" (75). The story suggests that Nance is lost for lack of faith - an almost religious kind of faith. The "day of the sheep," which can be read as a pun on the "day of the Lord," is not a Sun-day: there "should have been [...] sun" (69) but there is not, only rain, and the substitutive sheep, such a ubiquitous animal in New Zealand that it may well end up in someone's urban wash-house, is one that has lost its flock. The story is a discrete parable ${ }^{8}$ which amplifies Nance's feeling of being lost, while pointing at the source of that feeling, namely her failure to share the secret of the day, to rise above the grime of her daily life and see the poetic beauty of it. It is important to note that even though Frame uses the form of the parable, reading the story as a religious one would be reducing its meaning. As Derrida argues, a secret is not mystical (Passions 60), despite the religious origin of the term and the frequent association between the two (Donner 40), and although it deals with a form of faith - the faith in one's life. Frame uses the form of the religious parable to make this point.

8. Frame acquired a sense of parable at an early age, as she reports in her Autobiography: "Sometimes my walk took me, daringly, the length of Eden Street, past the Church of Christ near the corner, with its wayside Pulpit Thought For the Week, which I read carefully, taking literally the shortened parables about shepherds, sheep and sinners" (36). 


\section{Illegible secrets}

"Jan Godfrey" and "My Last Story" function as mirror stories: they could be read as the voice of one and the same person at different moments. They both focus on the inner, secret self, through the images of the mind and of the heart, and how undecipherable it remains. There is an ambiguity about whether the narrative voice in "Jan Godfrey" belongs to a single person or two different ones, but the fact is that it introduces the reader to two different personas, one being the first narrator (who may be Jan Godfrey), and the second, Alison Hendry. The narrator wants to write the story of Alison Hendry, the girl who shares her room, but keeps wandering away from it. She is obviously struggling to stick to a topic that escapes her, and instead gives the story of her successive stays in hospital. By trying to write the story of another person, she is both trying to escape from her (old) self and say something about her (inner) self. This is suggested in the image of the story as a present: "the loveliest [stories] are those that get written and are not torn up and are taken to a friend as payment for listening, for putting a wise ear to the keyhole of my mind" (131). As Simone Oettli has pointed out in her essay, this is an allusion to John Money, and an expression of gratitude for the time he spent listening to Frame during their counselling sessions in 1946 (101). The image of the ear to the keyhole is striking. A keyhole usually calls for an eye to spy through (in an echo of the children's game "I spy with my little eye something beginning with... you can never guess," 130) and perhaps see something happening behind closed doors that should remain out of sight. But here the friend is putting his ear to the keyhole, so sight is not called upon to understand the secret self. Furthermore, understanding does not depend on hearing but on listening, which here implies being sympathetic and understanding. The keyhole similarly suggests understanding through finding the key to someone's heart. The listener has not a voyeuristic eye, nor an indiscreet or intrusive ear, but a wise one; he is sympathetic. The secret self is not something to be unveiled, a whole to be revealed and understood, but rather, it is a voice that one should listen to, a mind that is worthy of attention.

The second persona of the story, Alison Hendry, is equally mysterious and secretive, but in a different way. She is less methodical in her speech, her voice wanders, too, but in a less controlled way than the first persona's. It sounds like an inner voice that contradicts itself:

I knit here in secret with my yellow needles going tap-tap tap-tap. [...] I am learning to be a tailoress. I sit and sew and do not speak. [...] I speak all the time though there are not many words to my speaking. [...] I am afraid. I am neither separate nor complete nor important. I have never been away from home before. $(134,135)$

What Alison's words suggest is that she needs to find out who she is. She has lived at home with an overbearing mother and does not have the autonomy of an adult, she is looking for her own identity, hoping to attain it by becoming a full-fledged tailoress. She also needs to find her voice, to speak up, to speak for herself; as it is she is underconfident and feels that she is some sort of extension of her overbearing mother ("neither separate"), someone not self-sufficient ("nor complete"), and not truly a person of her own ("nor important"). But all these things are not really spoken out, they remain her own secret, undecipherable both to the reader/listener and to herself. 
As much as the narrator of "Jan Godfrey" wants to tell a story, the narrator of "My Last Story" refuses to do so, opening the story with "I'm never going to write another story" $(181,182)$. This sentence is reiterated throughout the narrative, before the narrator concludes, "I think I must be frozen inside with no heart to speak of. I think I've got the wrong way of looking at Life" (183). That she has "no heart to speak of" suggests that she has no feelings to understand others and express what they feel and who they are (as in "My sister has a heart of gold," 183). But it also implies that she has no inner self to speak about, that she is empty, that she cannot speak of her heart, about her inner, secret self, because it is illegible, even to herself, and she cannot find adequate language to say what she wants to say ("I'm not going to do any more expressing," 183). Conventional ways of talking about one's inner self are not adequate. Frame's chosen mode of writing in "Jan Godfrey" is uncannily echoed in Derrida's concept of writing under erasure, through which the sign remains visible while being erased. Such erasure, Derrida argues, is the last writing of an era; it outlines ontology, the metaphysics of presence, and logocentrism; in that, this last writing is also the first writing (De la grammatologie 38) - "I'm going to begin..." (183). But, to continue paraphrasing Derrida, what about the writer's responsibility towards this illegible secret, this writing that goes against the logic of awareness, of intention, of wanting to say, of representation? To Derrida, sovereignty is proportional to the right one claims not to answer for these, to keep one's secret, not to be responsible for it to anyone - except perhaps God (Derrida qtd. in Michaux 25, 33). If this is so, then Frame is a very sovereign writer, and the originality and openness of her prose bear witness to that.

Towards the end of her three-volume autobiography, Frame meets Dr. Berger at the Maudsley Hospital in London, whom she hopes will help her find her "secret, true' self' (Autobiography 371). But perhaps that was the self Frame wanted to discover by the end of her autobiography, the self that would enable her to put an end to what had become the legend of the New Zealand schizophrenic writer who had narrowly escaped lobotomy thanks to her prize-winning book of stories. Indeed, medical expertise is there to prove it: she had been misdiagnosed. But one suspects that Frame's inner self is more complex than that. What we can surmise is this. When she wrote the Lagoon stories, Janet Frame was a twenty-one-year-old experimenting with the possibilities of literature. She claimed the possibility to say, and also not to say, in particular in metafictional stories such as "Jan Godfrey" and "My Last Story." Writing was her way of expressing what mattered most to her, without entirely disclosing a secret self that had been shaped by an acute sense of death, but that even she could not entirely fathom - something the "pathological readings" of her work (to use Lydia Wevers's phrase, 57) aim to do. Given her circumstances at the time, it was also a way for her to claim a crucial form of freedom

Christine LORRE, Université Sorbonne Nouvelle - Paris 3

\section{Works Cited}

Chevalier, Jean, and Alain GHeErbrant. Dictionnaire des symboles: mythes, rêves, coutumes, gestes, formes, figures, couleurs, nombres. Paris: Robert Laffont, 1982. 
Cronin, Jan, and Simone Drichel, eds. Frameworks: Contemporary Criticism on Janet Frame. Amsterdam \& New York: Rodopi, 2009.

Cronin, Jan. "Through a Glass Darkly: Reading the Enigmatic Frame." In Cronin and Drichel, 323.

DERRIDA, Jacques. Donner la mort. Paris: Galilée, 1999.

—. De la grammatologie. Paris: Minuit, 1967.

—. Passions. Paris: Galilée, 1993.

DrICHEL, Simone. "'Signposts to a world that is not even mentioned': Janet Frame's Ethical Transcendence." In Cronin and Drichel, 181-212.

Frame, Janet. "Alone on a River of Words: Interview with Rosemary Vincent." New Zealand Times 2 October 1983: 9. Qtd. in Drichel, 185.

—. An Autobiography. New York: George Braziller, 1991.

—. The Lagoon and Other Stories. 1951. London: Bloomsbury, 1997.

Guignery, Vanessa. "Is There a Short Story in Janet Frame's The Lagoon and Other Stories?" Études anglaises 63.3 (2010): 305-317.

JakOBSON, Roman. "Linguistique et poétique." Essais de linguistique générale. 1. Les fondations du langage. Paris: Minuit, 1963/2003. 209-248.

LORRE, Christine. "Narrative Voice and the Making of the Self: A Study of The Lagoon and Other Stories." Chasing Butterflies: Janet Frame's The Lagoon and Other Stories. Ed. Vanessa Guignery. Paris: Publibook, 2011. 125-144.

Michaux, Ginette. "Lui - la psychanalyse." Cabiers de l'Herne : Jacques Derrida. Ed. Marie-Louise Mallet and Ginette Michaud. Paris: L'Herne, 2004. 416-421.

—. Tenir au secret (Derrida, Blanchot). Paris: Galilée, 2006. 